\title{
A study on gastrointestinal tract characteristics of ram lambs at the same weights from six Turkish sheep breeds
}

\author{
A. Yıldırım ${ }^{1 \#}$, Z. Ulutaş ${ }^{1}$, N. Ocak ${ }^{2}$, E. Şirin ${ }^{3} \&$ Y. Aksoy ${ }^{1}$ \\ ${ }^{1}$ Department of Animal Science, Faculty of Agriculture, University of Gaziosmanpaşa, Tokat/Turkey \\ ${ }^{2}$ Department of Animal Science, Faculty of Agriculture, University of Ondokuz Mayıs, Samsun/Turkey \\ ${ }^{3}$ Department of Agricultural Biotechnology, Faculty of Agriculture, University of Ahievran, Kırşehir/Turkey
}

(Received 2 July 2013; Accepted 5 November 2013; First published online 30 March 2014)

\author{
Copyright resides with the authors in terms of the Creative Commons Attribution 2.5 South African Licence. \\ See: http://creativecommons.org/licenses/by/2.5/za \\ Condition of use: The user may copy, distribute, transmit and adapt the work, but must recognise the authors and the South African \\ Journal of Animal Science.
}

\begin{abstract}
A study was conducted, first, to compare the gastrointestinal tract (GIT), reticulo-rumens and intestinal capacities (relative to body weight) of ram lambs from six Turkish sheep breeds: Turkish Merino (TM, Anatolia Merino), Akkaraman (AK), Kıvırcık (KV), Awassi (AW), Karayaka (KY) and Morkaraman (MK), and second, to examine the influence of sheep breed on the $\mathrm{pH}$ of the digesta in the various segments (rumen, jejunum and caecum) of the GIT. Six ram lambs from each breed were slaughtered at $40.2 \pm 0.80 \mathrm{~kg}$ liveweight. Lambs from the AK breed had a heavier GIT weight than the AW, KY or MK breeds. The weight of the full stomach was higher in AK lambs compared with the other lambs, except for KV lambs, while the relative weight of the empty stomachs was heavier in MK ram lambs than in TM, AW and KY lambs. The AK lambs had the highest relative empty intestinal weight. The relative weight of empty intestines was heavier in $\mathrm{KV}$ lambs than in KY lambs. The pH of the rumen content was higher in TM and AK lambs compared with KY and $\mathrm{MK}$ lambs, while the $\mathrm{pH}$ of the caecum content of $\mathrm{KV}$ lambs was higher than those of $\mathrm{KY}$ and MK lambs. In conclusion, significant differences were found among the six breeds in terms of some variables that were studied, although a higher proportional GIT weight in the fat-tail breeds such as the MK, AK and AW was not reflected in all components or in the $\mathrm{pH}$ of the GIT content.
\end{abstract}

Keywords: Native sheep breed, digestive system, rumen, small and large intestine, $\mathrm{pH}$ value

\#Corresponding author: arda.yildirim@gop.edu.tr

\section{Introduction}

As in the rest of the world, all breeds of sheep in Turkey are important, but at any one time, some breeds are more important than others, because they best meet the current demands of the sheep industry and the consumers of sheep products. Furthermore, genetic resources of native sheep are a large source of income and are of great cultural value in many countries (Carneiro et al., 2010). Turkish Merino (TM, Anatolia Merino), Akkaraman (AK), Kıvırcık (KV), Awassi (AW), Karayaka (KY) and Morkaraman (MK) are common sheep breeds in Turkey (TurkStat, 2012). The main product of the AK, MK, KY and KV breeds is mutton, whereas AW is a multi-purpose sheep breed. Turkish or Anatolia Merino (TM) is a mutton-wool-type breed developed through crossbreeding the German Mutton Merino and the KV breeds. All these animals are breeds that range from small to medium size and are indigenous, except for the TM. These animals provide income, employment and food security to resource-limited farmers. The MK, AK and AW are fattailed breeds. The KV is a long-tailed breed, while the KY is long-thin-tailed breed. Many studies investigating the slaughter and carcass traits of the AK (Guler \& Aktumsek, 2011), AW (Sahin et al., 2003; Dikmen et al., 2009; Esenbuga et al., 2009; Kaya, 2011), MK (Esenbuga et al., 2001; 2009; 2011), KY (Olfaz et al., 2005; Sen et al., 2011; Yıldırım et al., unpublished data), KV (Ekiz et al., 2009) and TM (Ekiz et al., 2009) breeds have been conducted under experimental conditions.

The digestive or gastrointestinal system constitutes a series of tubular organs and associated glands whose main function is to break down the ingested food materials into smaller units that can be absorbed and utilized for the maintenance of the organism. Physiological factors that cause between-animal variation in digestive function are evaluated as possible selection traits to achieve improved growth, fattening performance and feed-use efficiency by sheep (Hegarty, 2004). Significant differences in digestive function existed between and within breeds (Hegarty, 2004), which may result in the differences in gastrointestinal 
tract (GIT) characteristics between and within breeds. The variation in weight of the digestive tract contents in lambs before slaughter causes a problem in evaluating some of the slaughter traits (e.g. dressing percentage). Indeed, a more developed digestive tract will be larger and heavier, which will decrease the dressing percentage of the animal (Mushi et al., 2009). The GIT of extensively produced lambs is more developed, due to the higher intake of dry matter compared with intensively produced animals of the same age (Priolo et al., 2002; Cañeque et al., 2003). However, the well-developed GIT of extensively reared animals could contribute to a higher slaughter weight of these animals compared with lambs in an intensive production system (Priolo et al., 2002).

Differences between and within sheep breeds in terms of body size, morphology and physiology are nutritionally important in judging local sheep breeds, which is important not only for preserving genetic diversity, but also for sustainable rural development in developing parts of the world (Carneiro et al., 2010). Steinheim et al. (2003) indicated a general difference in morphological and possibly physiological characteristics between short- and long-tailed sheep, and suggested that short-tailed sheep in general have a smaller digestive system, that is, a body mass ratio, than the heavier "modern" long-tailed breeds. Based on this finding and the suggestion that there may be a difference in morphological and possibly physiological characteristics between fat-, long- and long-thin-tailed sheep, further investigations are required. There has been insufficient information on some GIT characteristics such as absolute and relative (to body weight) weights of the whole GIT, reticulo-rumen and intestine, length of intestine and on the development of the GIT in these breeds when they were reared under the same feeding conditions (high-energy diet). The $\mathrm{pH}$ in the GIT content was 6.9, 7.3, 7.0 and 7.2 for the rumen, ileum, caecum and terminal colon, respectively, and the $\mathrm{pH}$ values of digesta from ruminants fed hay diets remained near neutrality in all segments of the GIT except the abomasum (Wheeler, 1980; Chaucheyras-Durand et al., 2010). However, a search of the literature indicated a lack of information on the $\mathrm{pH}$ of ingesta in the lower GIT of ram lambs fed high-energy diets. Accordingly, the objectives of the study were twofold: first, to compare the GIT, reticulo-rumens and intestinal capacities (relative to body weight) in ram lambs at the same weights from six common Turkish sheep breeds; and second, to examine the influence of sheep breed on the $\mathrm{pH}$ values of the contents in the various segments (rumen, jejunum and caecum) of the GIT.

\section{Materials and Methods}

The study was carried out at the experimental farm of Gaziosmanpaşa University, Faculty of Agriculture, Tokat, Turkey, situated at $40^{\circ} 31^{\prime} \mathrm{N}, 36^{\circ} 53^{\prime} \mathrm{E}$ and $650 \mathrm{~m}$ above sea level. Long-term average annual temperature and relative humidity in this region vary from 8.1 to $14.2{ }^{\circ} \mathrm{C}$ and between $56 \%$ and $73 \%$, respectively (MARA, 2009). The study was conducted in accordance with EC 8 Directive 86/609/EEC, and all animal procedures were approved by the local ethical committee of Gaziosmanpaşa University for Experimental Animals.

Six ram lambs from six indigenous sheep breeds (TM, AK, MK, AW, KY and KV) were used in the study. Purebred 90-day-old lambs of each breed, born within the same week, with approximately the same liveweight and body condition, were selected for the study. The lambs were vaccinated for enterotoxaemia and pleuropneumonia. The selected animals were fattened until they attained $40 \mathrm{~kg}$ liveweight. Concentrate feed, lucerne hay and water were given ad libitum during the fattening period. The experimental diet was formulated according to the nutrient requirements for fattening (NRC, 2007). The chemical composition of the feed supplements is presented in Table 1. Dry matter (method 930.15), crude protein (method 954.01) and crude fibre (method 962.10) contents of dietary ingredients were determined according to AOAC (2000).

The liveweight $(40 \mathrm{~kg})$ of the lambs was measured before they were slaughtered, following standard commercial slaughtering procedures (TSE, 1987), and all lambs were transported to an abattoir. Before slaughter, the lambs were fasted for 12 hours, but had free access to water. Then they were slaughtered by severing the throat and major blood vessels in the neck in local licensed abattoirs in their own areas of origin.

The anatomy of the ruminant digestive system includes the mouth, tongue, salivary glands, oesophagus, four-compartment stomach (rumen, reticulum, omasum and abomasum), pancreas, gall bladder, small intestine (duodenum, jejunum, and ileum) and large intestine (caecum, colon and rectum). Following exsanguination, empty reticulo-rumen and empty intestine weights were recorded (Balci \& Orman, 2008). Whole GIT and various segments of the GIT were weighed before complete emptying, and recorded as full weight. The rumen was opened, and the contents removed before the organ was washed by hand. The external fat was then removed. The small and large intestines were separated and contents were removed using a commercial slaughterhouse device. Fat adhering to the small and large intestines was trimmed and segments of each intestine were squeezed physically to remove the contents. The stomach (reticulo-rumen complex) was weighed after being squeezed dry, and the length of the intestine measured (Steinheim et al., 2003). Empty body weight was calculated as slaughter liveweight minus gut fill. Gut fill was 
calculated as the weight of the full stomach (reticulo-rumen complex) and intestines minus the weight of the emptied stomach complex and intestines. Intestine lengths were determined. Full and empty GIT, stomach and intestine weights were recorded (absolute weight) and expressed (relative weight) per unit of liveweight at slaughter.

Table 1 Ingredients of the concentrate feed and chemical composition of the concentrate feed and lucerne hay

\begin{tabular}{|c|c|c|c|c|c|}
\hline \multirow[b]{2}{*}{ Ingredients } & \multirow[b]{2}{*}{$\begin{array}{l}\text { Dry matter } \\
\mathbf{g} / \mathbf{k g}\end{array}$} & \multicolumn{3}{|c|}{ Chemical composition } & \multirow{2}{*}{$\begin{array}{r}\text { Total } \\
\mathbf{g} / \mathbf{k g}\end{array}$} \\
\hline & & $\begin{array}{c}\text { Crude protein } \\
\mathbf{g} / \mathbf{k g}\end{array}$ & $\begin{array}{c}\text { Crude fibre } \\
\mathrm{g} / \mathrm{kg}\end{array}$ & $\begin{array}{c}\mathrm{ME} \\
\mathrm{MJ} / \mathrm{kg}\end{array}$ & \\
\hline Concentrate feed & 884 & 136 & 88 & 11.1 & $800^{1}$ \\
\hline Barley & 885 & 100 & 69 & 11.7 & $420^{2}$ \\
\hline Maize & 860 & 75 & 21 & 11.6 & $181^{2}$ \\
\hline Wheat bran & 878 & 143 & 140 & 11.1 & $60^{2}$ \\
\hline Sunflower seed meal & 930 & 270 & 243 & 11.9 & $155^{2}$ \\
\hline DDGS & 891 & 290 & 80 & 11.9 & $88^{2}$ \\
\hline Molasses & 740 & 75 & - & 9.0 & $50^{2}$ \\
\hline Marble powder (Ca, 37\%) & & & & & $15^{2}$ \\
\hline Toxin binder & & & & & $10^{2}$ \\
\hline Vitamin-mineral mix ${ }^{*}$ & & & & & $1^{2}$ \\
\hline Lucerne hay & 900 & 153 & 287 & 8.1 & $200^{1}$ \\
\hline
\end{tabular}

ME: metabolisable energy; DDGS: dried distillers grain with solubles.

${ }^{1}$ In total diet $/ \mathrm{kg} ;{ }^{2}$ Total in concentrate $/ \mathrm{kg}$.

* Each $\mathrm{kg}$ vitamin and mineral mixture provided $20000000 \mathrm{lU}$ vitamin $\mathrm{A} ; 3000000$ vitamin $\mathrm{D}_{3} ; 20 \mathrm{~g}$ vitamin $\mathrm{E}$;

$4 \mathrm{~g}$ vitamin $\mathrm{B}_{1} ; 8 \mathrm{~g}$ vitamin $\mathrm{B}_{2} ; 12 \mathrm{~g}$ vitamin $\mathrm{B}_{5} ; 5 \mathrm{~g}$ vitamin $\mathrm{B}_{6} ; 20 \mathrm{mg}$ vitamin $\mathrm{B}_{12} ; 200 \mathrm{~g}$ choline; $50 \mathrm{~g} \mathrm{Mn} ; 50 \mathrm{~g} \mathrm{Fe}$;

$50 \mathrm{~g} \mathrm{Zn} ; 10 \mathrm{~g} \mathrm{Cu} ; 800 \mathrm{mg} \mathrm{I} ; 150 \mathrm{mg} \mathrm{Co} ; 150 \mathrm{mg} \mathrm{Se}$.

Before evisceration, the $\mathrm{pH}$ of the rumen, jejunum and caecum contents was determined immediately, using a digital pH meter (Sartorious PP15, AG Weender Landstrasse 94-108, Goettingen, Germany). The $\mathrm{pH}$ values were determined in six locations of the rumen, jejunum and caecum, because rumen and intestine digesta $\mathrm{pH}$ values are dependent on sampling location. The $\mathrm{pH}$ probe was kept in the rumen, duodenum and caecum until the $\mathrm{pH}$ reading was stabilized, and the $\mathrm{pH}$ value was recorded.

Data were analysed by one-way ANOVA to compare the six breeds. Thus the statistical model included the lone main effect of breed. Significant differences among means were detected using Duncan's multiple range test. Statistical analysis was performed using SPSS (version 17) statistical software (SPSS, 2008). Recorded absolute and relative weights and lengths, and all $\mathrm{pH}$ values studied are presented as means and a pooled standard error of mean (SEM). The level of statistical significance was set at $P \leq 0.05$.

\section{Results and Discussion}

Significant differences were recorded between the six breeds in terms of absolute and relative weights of GIT, full and empty stomach, and full and empty GIT, length of intestine and intestinal weight to intestinal length ratio (Table 2). Ram lambs from the AK breed had heavier absolute and relative weights of the GIT than the AW, KY and MK breeds $(P<0.001)$. The absolute weight of the full stomach was higher $(P<0.001)$ in AK ram lambs compared with other lambs. Similarly, the relative weight of the full stomach was higher $(P$ $<0.001$ ) in AK ram lambs compared with other lambs except for the KV lambs. The absolute weight of the empty stomach was heavier $(P<0.001)$ in MK ram lambs than in TM and KY ones whereas the relative weight of the empty stomach was heavier $(P<0.001)$ in MK ram lambs than in TM, AW and KY lambs. Lambs from the KY breed had a lower absolute weight $(P=0.053)$ and relative weight $(P=0.032)$ of the full intestine compared to those from the MK breed. Lambs from the MK breed had the highest absolute weight of the empty intestine; those from TM and KY breeds had the lowest absolute weight of the empty intestine compared with lambs from $\mathrm{AK}, \mathrm{KV}$ and $\mathrm{AW}$ breeds, which had a moderate value $(P<0.001)$. The AK ram lambs had the highest relative weight of the empty intestine compared with the other lambs $(P<0.001)$. The 
relative weight of the empty intestine was heavier $(P<0.001)$ in $\mathrm{KV}$ lambs than in $\mathrm{KY}$ lambs, whereas lambs from KV and MK had the longest intestine length compared with other lambs, and lambs from the AK and AW breeds had a shorter intestinal length compared with those from the KY breed $(P=0.058)$.

Table 2 Gastrointestinal tract characteristics of ram lambs from six Turkish sheep breeds ${ }^{1}$

\begin{tabular}{lcccccccr}
\hline & TM & AK & KV & AW & KY & MK & SEM & P \\
\hline Absolute weight (kg) of & & & & & & & & \\
Live & 40.0 & 40.6 & 40.1 & 40.6 & 40.4 & 39.9 & 0.13 & 0.501 \\
Gastrointestinal tract & $7.4^{\mathrm{ab}}$ & $9.0^{\mathrm{a}}$ & $7.5^{\mathrm{ab}}$ & $6.7^{\mathrm{b}}$ & $6.4^{\mathrm{b}}$ & $6.8^{\mathrm{b}}$ & 0.21 & $<0.001$ \\
Full stomach & $4.5^{\mathrm{b}}$ & $6.1^{\mathrm{a}}$ & $4.8^{\mathrm{b}}$ & $4.1^{\mathrm{b}}$ & $4.1^{\mathrm{b}}$ & $4.0^{\mathrm{b}}$ & 0.18 & 0.001 \\
Empty stomach & $1.0^{\mathrm{b}}$ & $1.2^{\mathrm{ab}}$ & $1.2^{\mathrm{ab}}$ & $1.1^{\mathrm{ab}}$ & $1.0^{\mathrm{b}}$ & $1.3^{\mathrm{a}}$ & 0.03 & 0.001 \\
Full intestine & $2.8^{\mathrm{a}}$ & $2.9^{\mathrm{a}}$ & $2.7^{\mathrm{ab}}$ & $2.6^{\mathrm{ab}}$ & $2.3^{\mathrm{b}}$ & $2.8^{\mathrm{a}}$ & 0.06 & 0.053 \\
Empty intestine & $1.0^{\mathrm{c}}$ & $1.2^{\mathrm{b}}$ & $1.3^{\mathrm{b}}$ & $1.2^{\mathrm{b}}$ & $1.0^{\mathrm{c}}$ & $1.6^{\mathrm{a}}$ & 0.04 & $<0.001$ \\
Relative weight (\%) of & & & & & & & & \\
Gastrointestinal tract & $18.4^{\mathrm{ab}}$ & $22.2^{\mathrm{a}}$ & $18.8^{\mathrm{ab}}$ & $16.5^{\mathrm{b}}$ & $15.8^{\mathrm{b}}$ & $17.0^{\mathrm{b}}$ & 0.52 & $<0.001$ \\
Full stomach & $11.4^{\mathrm{b}}$ & $15.1^{\mathrm{a}}$ & $12.1^{\mathrm{ab}}$ & $10.1^{\mathrm{b}}$ & $10.1^{\mathrm{b}}$ & $9.90^{\mathrm{b}}$ & 0.44 & 0.001 \\
Empty stomach & $2.6^{\mathrm{b}}$ & $2.9^{\mathrm{ab}}$ & $2.9^{\mathrm{ab}}$ & $2.6^{\mathrm{b}}$ & $2.5^{\mathrm{b}}$ & $3.2^{\mathrm{a}}$ & 0.06 & $<0.001$ \\
Full intestine & $7.1^{\mathrm{a}}$ & $7.1^{\mathrm{a}}$ & $6.7^{\mathrm{ab}}$ & $6.3^{\mathrm{ab}}$ & $5.7^{\mathrm{b}}$ & $7.1^{\mathrm{a}}$ & 0.15 & 0.032 \\
Empty intestine & $2.6^{\mathrm{bc}}$ & $3.1^{\mathrm{bc}}$ & $3.2^{\mathrm{b}}$ & $3.0^{\mathrm{bc}}$ & $2.4^{\mathrm{c}}$ & $3.9^{\mathrm{a}}$ & 0.10 & 0.001 \\
Intestine length (cm) & $36.6^{\mathrm{bc}}$ & $37.6^{\mathrm{b}}$ & $40.4^{\mathrm{a}}$ & $37.6^{\mathrm{b}}$ & $35.9^{\mathrm{c}}$ & $39.0^{\mathrm{a}}$ & 0.47 & 0.058 \\
WI to LI ratio (\%) & $2.8^{\mathrm{b}}$ & $3.3^{\mathrm{b}}$ & $3.2^{\mathrm{b}}$ & $3.2^{\mathrm{b}}$ & $2.8^{\mathrm{b}}$ & $4.0^{\mathrm{a}}$ & 0.08 & $<0.001$ \\
& & & & & & & &
\end{tabular}

TM: Turkish Merino; AK: Akkaraman; KV: Kivircik; AW: Awassi; KY: Karayaka; MK: Morkaraman. SEM: standard error of the mean.

${ }^{a-c}$ Means followed by different superscripts in each row are significantly different $(P<0.05)$.

${ }^{1}$ Values are means of six lambs for each breed.

WI to LI, The mean empty weight of the intestine to the mean length of the intestine ratio.

The results of the GIT tracts are in accordance with findings of previous studies on the digestive tract: on Norwegian sheep (Steinheim et al., 2003); on crossbred lambs from three genetic groups (Ribeiro et al., 2009); and on Mexican hair sheep (Ríos et al., 2011). In a study by Steinheim et al. (2003) it was demonstrated that breed had an effect on the rumen weight and small intestine length, and the long-tailed breed clearly had the heaviest rumen (indicating the largest rumen capacity) and the longest small intestine relative to body mass compared with the short-tailed breeds. Furthermore, short-tailed breeds have smaller rumens and a shorter intestine. Therefore, our results support the observation that the significant differences in weights of GIT organs owing to breed of lamb are correct (Steinheim et al., 2003; Ribeiro et al., 2009; Ríos et al., 2011) and are consistent with results on TM, AK and MK breeds in a study by Teke \& Ünal (2009) and results on KY breed in a study by Yıldırım et al. (unpublished data). Two of the breeds (KY and KV) have light long tails; one (TM) was a heavier crossbred with a long fat tail; and the other three breeds (AK, MK and AW) had moderate body weights and fat tails. Furthermore, lambs consuming concentrates had a small digestive tract, while forage-raised animals had a higher dry matter intake and thus a more developed digestive tract (Priolo et al., 2002). An increase in rumen and intestine capacity (relative to body weight) is associated with an increase in grass and roughage consumption and as GIT weights increase, intake enhances (Johnson et al., 1990; Finegan et al., 2001). Moreover, increased proportional GIT weight in lambs as a result of consuming forage appears to be reflected in all components of the GIT (Finegan et al., 2001). Based on these findings and information, the differences between the breeds studied in the present study may be the result of differences in their tail types, and not type of feed consumed, because all lambs were fed the same total mixed diet. Lambs with heavier full stomach and intestine weights may have lower carcass yields because the gastrointestinal content influenced carcass yield (Ríos et al., 2011). Nsoso et al. (2004) noted that different vegetation types promoted different body measurements, which should be expected owing to differences in nutrient supply from different vegetation types.

The GIT has a major impact on energy expenditure, and about $20 \%$ to $25 \%$ of the total energy could be attributed to the organs in the GIT (Ferrell, 1988; Finegan et al., 2001). Furthermore, the larger organ size 
would result in a greater energy requirement (Fluharty et al., 1999). It is interesting that the mean empty weight of the intestine to the mean length of the intestine ratio was higher $(P<0.001)$ in MK ram lambs than in the other breeds (Table 2). The higher weight of the rumen and small intestine is an indication that they contribute to improving the efficiency of feed utilization in animals (Priolo et al., 2002). Amount and type of feed consumed, breed, age, sex and environmental conditions are known to contribute to between-animal variation in efficiency of feed utilization for maintenance and growth (Channon et al., 2004). However, it was not clear whether lambs were more efficient in terms of feed intake and feed efficiency owing to the difference in relative empty GIT weights, since data were not available on the amount of feed consumed by lambs in the present study. Furthermore the fat-tailed breeds used in the present study were statistically different in terms of some variables studied and a higher proportional GIT weight in lambs were not reflected in all components of the GIT (Table 2), contrary to the findings of Finegan et al. (2001).

Differences because of breed of lamb were significant in the $\mathrm{pH}$ of the rumen $(P<0.001)$ and caecum $(P=0.020)$ contents (Table 3). The $\mathrm{pH}$ of the rumen content was higher $(P<0.001)$ in TM and AK lambs compared with $\mathrm{KY}$ and $\mathrm{MK}$ lambs, while the caecum content $\mathrm{pH}$ of $\mathrm{KV}$ lambs was higher $(P=0.020)$ than those of KY and MK lambs. Rumen content pH typically ranged from 6.5 to 6.8 , and most rumen microbes can only thrive in this type of environment (Franzolin \& Dehority, 2010; Franzolin et al., 2010). The pH values in the contents of all segments of the GIT obtained in the present study were within the values obtained by other researchers feeding high-energy diets. Although specific activity of pancreatic amylase was observed to increase when high concentrate diets were fed to sheep (Russell et al., 1981), the intestinal pH of ram lambs in the present study may be below the 6.9 essential for optimal activity of pancreatic alpha amylase (Wheeler, 1980). Ruminal pH drops below physiological levels when ruminants consume excessive amounts of rapidly fermentable (non-fibre) carbohydrates (Wheeler, 1980; Krause \& Oetzel, 2006). Krause \& Oetzel (2006) noted that to maintain ruminal $\mathrm{pH}$ within a physiological range of about $5.5-7.0$, ruminants possess highly developed systems such as careful regulation of feed intake, and the ability of the rumen to rapidly absorb organic acids. Therefore, the differences in influence of breed on GIT pH may be explained by differences in the nature of the regulation of ruminal $\mathrm{pH}$ described above. Channon et al. (2004) noted that low faecal $\mathrm{pH}$ and faecal dry matter content were associated with lower efficiency (i.e. higher residual feed intake). Therefore the feed efficiency of lambs from KY and MK breeds may be higher than those of the KV breed. On the other hand, volatile fatty acid concentrations are high in the rumen of grain-fed animals, and the $\mathrm{pH}$ may vary from 5.0 to 6.5 , whereas in hay-fed animals, less fermentation occurs in the rumen, and the $\mathrm{pH}$ remains between 6.5 and 7 (Chaucheyras-Durand et al., 2010). Accordingly, less fermentation in the rumen of TM and AK ram lambs might have occurred than in the KY and MK lambs.

Table 3 Gastrointestinal tract $\mathrm{pH}$ of ram lambs from six Turkish sheep breeds ${ }^{1}$

\begin{tabular}{llllllllr}
\hline & TM & AK & KV & AW & KY & MK & SEM & \multicolumn{1}{c}{} \\
\hline Rumen pH & $7.15^{\mathrm{a}}$ & $7.09^{\mathrm{a}}$ & $6.84^{\mathrm{ab}}$ & $6.78^{\mathrm{ab}}$ & $6.46^{\mathrm{b}}$ & $6.60^{\mathrm{b}}$ & 0.06 & $<0.001$ \\
Jejunum pH & 6.28 & 6.33 & 6.62 & 6.46 & 6.44 & 6.56 & 0.04 & 0.221 \\
Caecum pH & $6.79^{\mathrm{ab}}$ & $6.68^{\mathrm{ab}}$ & $6.81^{\mathrm{a}}$ & $6.66^{\mathrm{ab}}$ & $6.40^{\mathrm{b}}$ & $6.46^{\mathrm{b}}$ & 0.04 & 0.020
\end{tabular}

TM: Turkish Merino; AK: Akkaraman; KV: Kivircik; AW: Awassi; KY: Karayaka; MK: Morkaraman.

SEM, standard error of the mean.

${ }^{a-c}$ Means followed by different superscripts in each row are significantly different $(P<0.05)$.

${ }^{1}$ Values are means of six lambs for each breed.

\section{Conclusion}

Significant differences were found among the six breeds in terms of absolute and relative weights of GIT, full and empty stomach, and full and empty intestine, length of intestine and intestine weight to intestine length ratio and also the GIT pH. However, higher proportional GIT weights in the fat-tail breeds such as the $\mathrm{MK}, \mathrm{AK}$ and $\mathrm{AW}$ were not reflected in all components and in the GIT $\mathrm{pH}$. The precise $\mathrm{pH}$ thresholds for subtle reduction or variation of feed intake and risk of developing ruminal acidosis in these breeds require further study since differences owing to breed of ram lambs were significant in rumen and caecum $\mathrm{pH}$ values. The present approach would help to a large extent in establishing management and conservation policies for the sustainable production of the six sheep breeds because the characterization of the sheep populations will play a major role in the maintenance of the genetic resources and also in nutrient supply from different vegetation types. 


\section{Acknowledgements}

The authors are thankful to the staff in the Department of Animal Science, Faculty of Agriculture, University of Gaziosmanpaşa, Tokat, Turkey.

\section{References}

AOAC, 2000. Official Methods of Analysis, $17^{\text {th }}$ ed. Association of Official Analytical Chemists, Washington, DC, USA.

Balci, F. \& Orman, A., 2008. The effects of short-term recombinant bovine somatotropin treatment on fattening performance, carcass composition and visceral organ weights in Karayaka lambs in Turkey. Trop. Anim. Health Prod. 40, 255-260.

Cañeque, V., Velasco, S., Díaz, M.T., De Huidobro, F.R., Pérez, C. \& Lauzurica, S., 2003. Use of whole barley with a protein supplement to fatten lambs under different management systems and its effect on meat and carcass quality. Anim. Res. 52, 271-285.

Carneiro, H., Louvandini, H., Paiva, S.R., Macedo, F., Mernies, B. \& McManus, C., 2010 Morphological characterization of sheep breeds in Brazil, Uruguay and Colombia. Small Rumin. Res. 94, 58-65.

Channon, A.F., Rowe, J.B. \& Herd, R.M., 2004. Genetic variation in starch digestion in feedlot cattle and its association with residual feed intake. Aust. J. Exp. Agr. 44, 469-474.

Chaucheyras-Durand, F., Faqir, F., Ameilbonne, A., Rozand, C. \& Martin, C., 2010. Fates of acid-resistant and non-acidresistant Shiga toxin-producing Escherichia coli strains in ruminant digestive contents in the absence and presence of probiotics. Appl. Environ. Microbiol. 76, 640-647.

Dikmen, S., Ustuner, H., Turkmen, I.I. \& Ogan, M., 2009. Fattening performance and feed source preference of native Awassi lambs fed individually in a cafeteria feeding system. Trop. Anim. Health Prod. 41, 485-491.

Ekiz, B., Yilmaz, A., Ozcan, M., Kaptan, C., Hanoglu, H., Erdogan, I. \& Yalcintan, H., 2009. Carcass measurements and meat quality of Turkish Merino, Ramlic, Kivircik, Chios and Imroz lambs raised under an intensive production system. Meat Sci. 82, 64-70.

Esenbuga, N., Yanar, M. \& Dayioglu, H., 2001. Physical, chemical and organoleptic properties of ram lamb carcasses from four fat-tailed genotypes. Small Rumin. Res. 39, 99-105.

Esenbuga, N., Macit, M., Karaoglu, M., Aksakal, V., Aksu, M.I., Yoruk, M. \& Gül, M., 2009. Effect of breed on fattening performance, slaughter and meat quality characteristics of Awassi and Morkaraman lambs. Livest. Sci. 123, 255-260.

Esenbuga, N., Macit, M., Karaoglu, M., Aksakal, V., Yoruk, M.A., Gül, M., Aksu, M.I. \& Bilgin, Ö.C., 2011. A study on possibility of Rosa canina seed use as feed Ingredient in diets of Morkaraman male lambs. Trop. Anim. Health Prod. 43, 1379-1384.

Ferrel, C.L., 1988. Contribution of visceral organs to animal energy expenditures. J. Anim. Sci. 66, 23-34.

Finegan, E.J., Buchanan-Smith, J.G. \& McBride, B.W., 2001. The role of gut tissue in the energy metabolism of growing lambs fed forage or concentrate diets. Br. J. Nutr. 86, 257-264.

Fluharty, F.L., McClure, K.E., Solomon, M.B., Clevenger, D.D. \& Lowe, G.D., 1999. Energy source and ionophore supplementation effects on lamb growth, carcass characteristics, visceral organ mass, diet digestibility, and nitrogen metabolism. J. Anim. Sci. 77, 816-823.

Franzolin, R. \& Dehority, B.A., 2010. The role of $\mathrm{pH}$ on the survival of rumen protozoa in steers. Rev. Bras. Zootecn. 39, 2262-2267.

Franzolin, R., Rosales, F.P. \& Soeras, W.V.B., 2010. Effects of dietary energy and nitrogen supplements on rumen fermentation and protozoa population in buffalo and zebu cattle. Rev. Bras. Zootecn. 39, 549-555.

Guler, G.O. \& Aktumsek, A., 2011. Effect of feeding regime on fatty acid composition and conjugated linoleic acid content of perirenal, omental and tail fat in Akkaraman lambs. Afr. J. Biotechnol. 10, 7099-7108.

Hegarty, R.S., 2004. Genotype differences and their impact on digestive function of ruminants: A review. Aust. J. Exp. Agr. 44, 459-467.

Johnson, D.E., Johnson, K.A. \& Baldwin, R.L., 1990. Changes in liver and gastrointestinal tract energy demands in response to physiological workload in ruminants. J. Nutr. 120, 649-655.

Kaya, S., 2011. The effects of outdoor housing and cafeteria feeding on growth performance and feeding behaviour of Awassi lambs kept in hot climate condition. J. Anim. Vet. Adv. 10, 2550-2556.

Krause, K.M. \& Oetzel, G., 2006. Understanding and preventing subacute ruminal acidosis in dairy herds: A review. Anim. Feed Sci. Technol. 126, 215-236.

MARA, 2009. The Master Plan of Tokat Province, Tokat, Statistical Data of Tokat Province, Tokat, Turkey.

Mushi, D.E., Safari J., Mtenga L.A., Kifaro, G.C. \& Eik, L.O., 2009. Growth and distribution of non-carcass components of Small East African and F1 Norwegian crossbred goats under concentrate diets. Livest. Sci. 126, 80-86. 
NRC, 2007. Nutrient Requirements of Small Ruminants: Sheep, Goats, Cervids, and New World Camelids. 6th. ed. National Academy Press Washington, DC, USA.

Nsoso, S.J., Podisi, B., Otsogile, E., Mokhutshwane, B.S. \& Ahmadu, B., 2004. Phenotypic characterization of indigenous Tswana goats and sheep breeds in Botswana: continuous traits. Trop. Anim. Health Prod. 36, 789-800.

Olfaz, M., Ocak, N., Erener, G., Cam, M.A. \& Garipoğlu, A.V., 2005. Growth, carcass and meat characteristics of Karayaka growing rams fed sugar beet pulp, partially substituting for grass hay as forage. Meat Sci. 70, 7-14.

Priolo, A., Micol, D., Agabriel, J., Parche, S. \& Dransfield, E., 2002. Effect of grass or concentrate feeding systems on lamb carcass and meat quality. Meat Sci. 62, 179-185.

Ribeiro, E.L.de A., Oliveira, H.C., de Castro, F.A.B., Mizubuti, I.Y., Da Silva, L. das D.F. \& Barbosa, M.A.A. de F., 2009. Performance in feedlot and non carcass components in crossbred lambs from three genetic groups. Ciênc. Rural. 39, 2162-2168 (in Portuguese).

Ríos, F.G., Gómez-Vázquez, A., Pinos-Rodríguez, J.M., García-López, J.C., Estrada-Angulo, A., HernándezBautista, J. \& Portillo, J.J., 2011. Effect of breed on performance and carcass characteristics of Mexican hair sheep. S. Afr. J. Anim. Sci. 41, 275-279.

Russell, J.R., Young, A.W. \& Jorgensen, N.A., 1981. Effect of dietary corn starch intake on pancreatic amylase and intestinal maltase and $\mathrm{pH}$ in cattle. J. Anim. Sci. 52, 1177-1182.

Sahin, A., Keskin, M., Bicer, O. \& Gul, S., 2003. Diet selection by Awassi lambs fed individually in a cafeteria feeding system. Livest. Prod. Sci. 82, 163-170.

Sen, U., Sirin, E., Ulutas, Z. \& Kuran, M., 2011. Fattening performance, slaughter, carcass and meat quality traits of Karayaka lambs. Trop. Anim. Health Prod. 43, 409-416.

SPSS, 2008. Statistics Base 17.0 for Windows user's guide. SPSS inc., Chicago, IL, USA.

Steinheim, G., Nordheim, L.A., Weladji, R.B., Holand, Ø. \& Ådnøy, T., 2003. Digestive tract anatomy of Norwegian sheep: Difference between breeds. Acta Agr. Scand. A-An. 53, 155-158.

Teke, B. \& Ünal, N., 2009. The effects of slaughter weight and sex on some slaughter traits of Akkaraman and Morkaraman and Turkish Merino lambs. Ankara Üniv. Vet. Fak. Derg. 56, 289-164.

TSE, 1987. Turkish Standards Institute. TS 52737 Butchery Animals-Rules for Slaughtering and Carcass Preparation, Ankara.

TurkStat, 2012. Livestock Statistics, Turkish Statistical Institute, http://www.turkstat.gov.tr (accessed August 07, 2013).

Wheeler, W.E., 1980. Gastrointestinal tract pH environment and the influence of buffering materials on the performance of ruminants. J. Anim. Sci. 51, 224-235. 